\title{
RATIONALISM AND REINCARNATION
}

\author{
KenNeTH BLACKWELL \\ BLACKWK@MCMASTER.CA
}

Paul Edwards. Reincarnation: a Critical Examination. Buffalo: Prometheus Books, 1996. Pp. 313. Us $\$ 28.95$.

I personally cannot see how Principia Matbematica could ever have been completed if Russell and Whitehead had not started on it long before they were born. (P. 50)

D aul Edwards' witty destruction of the arguments used on behalf of karma 1 and reincarnation (or the transmigration of souls) doesn't include the only known reference to karma ascribed to Russell: "Mommy, guess what? Bertie doesn't believe in karma", a child friend is quoted in Clark (p. 469). But the book includes plenty of other citations of Russell as Edwards goes about debunking this "intellectual rubbish". To these citations could be added Russell's most extended discussion of the transmigration of souls (in Plato; see HWP, pp. 145, 148), and his rebuttal of McTaggart's arguments based on love at first sight and hat-selection as analogous to the soul's selection of its next "parents" (Papers I2: 32I-2). One of Edwards' citations is of a book called Reincarnation in World Thought, by Head and Cranston, which offers a passage in which Russell describes his little boy's inability to believe there has been a past without him in it $(O E$, p. 17I). The same book cites the other "Cambridge Reincarnationists", Russell's friends Ward and Dickinson, for allowing the bare possibility of the recycling of souls sans memory. These are examples of the intellectual level of reincarnationists today.

Why should Edwards spend time on such arguments when, to rationalists, 
they are parently absurd or without empirical foundation? Because there is widespread belief in them. Edwards says of the influential Dr. Elisabeth Kuibler-Ross that she's never heard an argument for life after death that she doesn't endorse (p. 52). Some people presumably make decisions based on reincarnationist beliefs, and others make money on retailing reports of astral adventures. Certainly there is an active life in the present for the anti-reform argument that people's miseries need not be mitigated because they've brought them upon themselves for their (souls') sins in previous lives.

Edwards is at his most devastating in discussing the "interregnum", where souls await their next body, and the absurdities of "astral clothing". He shows that we don't need reincarnationist beliefs. He shows, too, that we are strongly compelled to believe positively in other directions. He is at his most scientific in grounding the mind's dependence on the body, and in this he is most affecting in tracing the undoubted wasting of mind well before death in the case of Alzheimer's patients. The book is salutary in revealing the persistence of nonsense and the persisting need for education, logic and good sense. 